Est Ag35 (2000) 49-77

\title{
Estructura de la Regla de San Agustín (VIII)
}

\subsection{El salmo 37}

El salmo 372 es uno de los siete salmos penitenciales. Contiene la exposición cronológica de las fases de un conocido proceso humano, con una dimensión teológica y espiritual: pecado, enfermedad sufrida, sentida como castigo de Dios, efectos sociales en amigos y enemigos, confesión del pecado y súplica de auxilio. Entra en el género literario que lleva por nombre «oración del enfermo arrepentido» 3.

\subsubsection{La Enarratio in psalmum 374}

Como ya indicamos en nuestro anterior artículo ${ }^{5}$, el presente texto no figuraba en el elenco de los que en su momento señalamos como objeto de nuestro análisis ${ }^{6}$. Entonces aún no habíamos percibido su interés para nuestro estudio. Pero una lectura detenida y atenta nos ha advertido de su utilidad para entender la estructura de la Regla de san Agustín 7. En efecto, la división que el santo hace del salmo nos pone en la órbita de ideas que creemos sostienen estructuralmente la Regla.

1. Cf. Estructura de la Regla de san Agustín (I-VII), en Estudio Agustiniano 32 (1997) 407-430; 33 (1998) 5-53; 227-270; 487-524; 34 (1999) 5-29; 219-247; 539-576.

2. Según los LXX y la Vulgata, no según la Biblia hebrea en la que aparece con el número 38.

3. L. Alonso SCHÖKEL- C.CARNiti, Salmos I. Estella 1992, p. 568.

4. En adelante, en. Ps. 37. Al número añadiremos la página del vol 38 del CC.

5. Cf. Estructura (VII), en Estudio Agustiniano 34 (1999) p.540.

6. Cf. Estructura (II), en Estudio Agustiniano 33 (1998) p. 5.

7. Ya dice el santo, aunque en otro contexto, que cuanto más penetrantemente mira uno, tanto más ve (De ciu. Dei 16,23: PL 41,500). 


\subsubsection{La enarratio in psalmum 37 y la exégesis prosopológica}

La exégesis prosopológica constituye una de las claves de la interpretación agustiniana de los salmos en general. Es uno de los legados que la exégesis cristiana recibió de la antigüedad clásica. Utilizada en la exposición de los textos de Homero y de Platón, fue practicada por los Padres de la Iglesia ya desde san Justino. Aplicado el método a los salmos, trata de identificar los diversos interlocutores que intervienen en el diálogo. Por ejemplo, si el Tú divino presente en ellos es el Padre o el Hijo, o quién es el que propiamente pronuncia el salmo, o si habla en nombre propio o en el de otra persona, etc. ${ }^{8}$. En este contexto se entiende la praxis agustiniana de interpretar los salmos como oración del totus Christus 9.

La en. Ps. 37 es uno de los textos donde aparece más diáfano el uso de dicho método por el obispo de Hipona. Su interpretación es poco lineal, pues se producen continuos cambios de perspectiva, aunque manteniendo siempre la atribución al totus Christus como único sujeto. El contenido del versículo 4, una confesión de los pecados (Non est pax ossibus meis a facie peccatorum meorum), le lleva a la necesidad de entenderlo como palabra de Cristo en nombre de su cuerpo, aquí identificado con Adán y la humanidad ${ }^{10}$. La enfermedad ulteriormente descrita (vv. 4-11) la atribuye directamente a Adán, a la humanidad, al hombre que ya vive en el cuerpo de Cristo, a la vez que ve cumplidos en la pasión de Cristo el abandono por parte de los amigos y el acoso de parte de los enemigos (vv. 12-16). Mas como Cristo, en atención a su cuerpo, quiso que fueran suyos nuestros pecados, así también nosotros, en atención a nuestra cabeza, queremos que sean nuestros sus sufrimientos. Con las palabras siguientes del salmo, que hablan de tropiezos (v. 17), de culpa y pecado (v. 19), cambia de nuevo de perspectiva al interpretarlas como pronunciadas por la Cabeza en atención a la debilidad de su Cuerpo. Perspectiva que varía todavía una vez más a propósito de los lamentos sobre el mal sufrido y la ignominiosa condena (v. 21), que refiere a Cristo sufriente hablando en

8. M. Fiedrowicz, Psalmus vox totius Christi. Studien zu Augustins «Enarrationes in Psalmos», Herder Freiburg in Breisgan 1997, p. 238-239.

9. M.J. RondeAU, Les Commentaires patristiques du Psautier (IIIe-Ve siècles) I y II, Roma 1982-1985.

10. «Quaeri solet cuius sit uox; et aliqui accipiunt Christi, propter quaedam quae hic dicuntur de passione Christi, ad quae paulo post ueniemus, et nos agnoscemus quia de passione Christi dicuntur. Sed: Non est pax ossibus meis a facie peccatorum meorum, quomodo diceret qui nullum peccatum habebat? Coarctat nos ergo intelligendi necessitas ad cognoscendum tanquam plenum et totum Christum, id est, caput et corpus...» (en. Ps. 37,6: 386). 
nombre propio, y del grito de ayuda No me abandones, Señor Dios mío (v. 22), que lo ve pronunciado en nombre del pecador alejado de Dios ${ }^{11}$.

Tenemos, pues, a Cristo que habla en nombre de Adán (confesión de los pecados); a Adán directamente, aunque ya integrado en Cristo (descripción de la enfermedad), a Cristo en persona (abandono y acoso), Cristo Cabeza en atención a la debilidad de su cuerpo (tropiezos, culpa y pecado), Cristo sufriente en nombre propio (lamentos sobre el mal sufrido e ignominiosa condena) y en nombre del pecador (grito de ayuda).

\subsubsection{Estructura de en. Ps. 37.}

Visto ya quién habla en el salmo y en nombre de quién, pasemos a la estructura conforme a la cual organiza los diversos sufrimientos. El predicador se expresa de la siguiente manera:

En efecto, algunos sufrimientos le llegan (al hombre) de su propia realidad personal; otros, en cambio, le llegan de fuera; esto es, de aquellos entre quienes vive. Sufre los males inherentes a su persona y se ve obligado a sufrir también los males ajenos. Esto da razón de aquellas dos frases: Limpiame de mis (pecados) ocultos, y ahorra a tu siervo los ajenos (Sal 18,13-14) 12.

Dos son, pues, la fuentes de los males: la propia realidad personal -así hemos traducido el ex se intrinsecus-y otra exterior (forinsecus), es decir, los demás. Aunque los males a que se refiere son de carácter «físico», son inseparables del mal moral, del pecado, su causa. De ahí la cita de Sal 18.

A su vez, a propósito del comentario del versículo 8 del salmo (porque mi alma está llena de «ilusiones» y mi carne no conoce la salud), leemos con anterioridad:

Así, pues, donde se da el hombre entero, hay alma y hay carne. El alma está llena de «ilusiones», la carne carece de salud. ¿Queda alguna fuente de alegría? ¿No conviene, acaso, que vivamos en la tristeza? Todo el día caminaba

11. M. FIEDrowicz, Psalmus vox totius Christi, p. 351.

12. «Patitur enim ex se intrinsecus, forinsecus autem ex eis inter quos uiuit: patitur mala sua, cogitur pati et aliena. Inde sunt illae duae uoces: $A b$ occultis meis munda me, Domine, et ab alienis parce seruo tuo» (en. Ps. 37,16 CC 38,393). 
entristecido (Sal 37,7). Sintámonos tristes hasta que nuestra alma se despoje de las «ilusiones» y nuestro cuerpo se revista de salud ${ }^{13}$.

El presente texto ha de entenderse como explicitación de algo que el anterior presentaba de modo sintético. Si aquel hablaba genéricamente de sufrimientos que provienen de la propia realidad personal, el presente establece una ulterior distinción: los que provienen del cuerpo (carne), la falta de salud, y los que provienen del alma, las abundantes «ilusiones» que en ella encuentran cobijo ${ }^{14}$.

Si unimos ambos textos es posible establecer una estructura en la que el santo integra los diversos males sufridos por el hombre. Es la siguiente:

Nos 4-10 (vv.4-7): males personales (cuerpo): Mi carne no conoce la salud (v. 4).

Nos 11-15 (vv. 8-11): males personales (alma): Mi alma está repleta de «ilusiones» (v. 8).

Nos 16-27 (vv. 12-22): "males ajenos" Mis amigos y mis parientes se me acercaron y se plantaron contra mí (v. 12).

Otorgando a cada grupo una denominación, podemos hablar de «unidad segunda», «unidad primera» $\mathrm{y}$ «unidad tercera» respectivamente, para ser fieles a la terminología usada en los artículos anteriores. Como, por otra parte, cada una de estas unidades consta de dos momentos, uno en el que propiamente expone los males y otro en el que presenta la referencia cristológica de los mismos, designamos a cada uno de estos momentos como «sección B» $\mathrm{y}$ «sección C» respectivamente.

Pero el lector habrá advertido que en esta estructura faltan los nos 1-4 de la enarratio, correspondientes a los vv. 1-3 del salmo, y el $\mathrm{n}^{\circ} 28$, correspon-

13. «Quoniam anima mea completa est illusionibus, et non est sanitas in carne mea. Vbi ergo est totus homo, anima et caro est. Anima completa est illusionibus, caro sanitatem non habet: quid remanet unde sit laetitia? Nonne oportet ut contristetur? Tota die contristatus ambulabam. Tristitia nobis sit, donec et anima nostra exuatur illusionibus, et corpus nostrum induatur sanitate. Illa enim est uera sanitas, quae est inmortalitas» (en. Ps. 37,11:389). «... et forte dolores quos hic necesse est pati, et animi et corporis, ipsas dicit sagittas» (en. Ps. 37,5: 385$)$.

14. Esta sección la concluye formalmente san Agustín con el $n^{\circ} 15$. Le pone término con las siguientes palabras: «Haec patitur homo intus, ibi secum, in seipso, et seipsum, de nemine ad neminem praeter se; haec sibi ipse poena sua esse meruit, quidquid superius enumerauit» (en. Ps. 37,15: 393). 
diente al v. 23. De los cuatro números iniciales, el primero tiene puro valor de introducción, mientras que los otros tres son ya propiamente comentario del salmo y su contenido central se resume en la idea del «sábado». En lógica con ello, al $\mathrm{n}^{\circ} 1$ lo podemos considerar como prólogo, y a los tres restantes como «sección A». A su vez, el no 28 describe la «salud» que Dios aportará al cristiano en los tiempos escatológicos. Podemos considerarlo como epílogo.

Brevemente se puede presentar como estructura de en. Ps. 37 la siguiente:
a) Prólogo.
Sección A.
Sección B (unidad segunda, primera y tercera).
Sección C (unidad segunda, primera y tercera).
b) Epílogo.

Como se puede percibir a simple vista las divergencias estructurales respecto de la que venimos ofreciendo para la Regla son mínimas, comparadas con las convergencias. Aquellas se reducen al hecho de que, como iremos viendo a continuación, las secciones $\mathrm{B}$ y $\mathrm{C}$ aparecen integradas dentro de cada unidad, y al orden entre las dos primeras unidades, que no se corresponden tal cual, sino que aparecen intercambiadas.

Pero todo continente -y una estructura es un continente- puede llenarse con diversos contenidos. Por ello, una vez percibida la identidad fundamental de estructura entre la en. Ps. 37 y la Regla, procede examinar también los contenidos y ver si se da idéntica coincidencia. En un primer momento nos limitamos a llenar de contenido la estructura de en. Ps. 37. Sólo después estableceremos la comparación con la Regla.

\subsubsection{Prólogo $\left(n^{\circ} 1\right)$}

No comenta ningún versículo del salmo. Agustín se limita a establecer la relación entre el salmo, que había sido leído como salmo responsorial en la liturgia, y la escena de la cananea (Mt 15,21-28), lectura evangélica del día ${ }^{15}$.

15. El predicador menciona sólo el v. 19 (Iniquitatem meam ego pronuntio et curam geram pro peccato meo) del salmo, que había hecho de estribillo cantado, y el versillo 26 del relato evangélico (Non est bonum, panem filiorum mittere canibus). 
Como suele ser habitual en él, reclama la atención de los oyentes, y pide la presencia del Señor en el corazón del predicador y de los fieles.

\subsubsection{Sección $A$ (vv. 1-3; nos 2-4)}

Como tantas otras veces, el predicador descubre en el título del salmo la clave para su interpretación. El título es el siguiente: Salmo de David, para recuerdo del sábado (v. 1). En busca de una interpretación histórica, no encuentra en la vida del salmista ningún acontecimiento a que pueda referirse el texto. El sábado era institución que había que celebrar, no que recordar ${ }^{16}$. $\mathrm{Al}$ no encontrar interpretación que se ajuste con la historia, busca la espiritual: «¿Qué significa este recordar el sábado, hermanos míos?» 17. A su parecer, el sentido sólo cabe deducirlo de las características de dicho sábado tal como aparecen en el salmo: un sábado que se recuerda entre sollozos y llanto, indicadores sí de miseria, pero también del anhelo de la felicidad futura, en la línea de las bienaventuranzas ${ }^{18}$. ¿Quién es ese que así llora? El predicador expresa el deseo de que sean todos los allí presentes, porque el sábado por el que se solloza y gime no es otra cosa que el descanso eterno 19.

El obispo de Hipona no olvida que el estribillo cantado expresaba cierta preocupación a causa del propio pecado. Tal preocupación, que oculta un temor, aparece referida en el segundo versículo del salmo: Señor, no me arguyas cuando estés indignado, ni me enmiendes cuando estés airado ${ }^{20}$. Palabras a las que da un sentido escatológico, vinculándolas a la escena del juicio final.

16. «... et inter bona quae de illo nobis nota sunt per scripturas, non inuenimus eum aliquando recordatum sabbatum... Obseruandum ergo erat, non sic recordandum» (en. Ps. 37 2:383).

17. «Quid sibi uult ista recordatio sabbati, fratres mei?» (en. Ps. 37,2:383).

18. «Quod est hoc sabbatum? Cum gemitu enim recordatur. Et cum psalmus legeretur, audistis, et modo cum relexerimus, audietis quantus sit maeror, quantus gemitus, quantus fletus, quae miseria. Sed felix est, qui sic miser est. Vnde et Dominus in euangelio beatos appellauit quosdam lugentes (cf. Mt 5,5)» (en. Ps. 37,2: 382).

19. «Talem ergo et hic accipiamus sabbatum recordantem, nescio quem lugentem; et utinam nos simus ipse nescio quis! Est enim quidam dolens, gemens, lugens, recordans sabbatum. Sabbatum, requies est» (en. Ps. 37,2: 383).

20. «Ipse itaque inquietudinem quam patiebatur, narrat et commendat Deo, nescio quid gravius timens quam erat ubi erat. Nam quia in malo est, aperte dicit, nec interprete opus est, nec suspicione, nec coniectura; in quo malo sit non dubitatur ex eius uerbis, nec opus est ut quaeramus, sed ut quod dicit intellegamus. Et nisi peius aliquid timeret, quam erat illud quo tenebatur, non sic inciperet: Domine, ne in indignatione tua arguas me neque in ira tua emendes me» (en. Ps. 37,3: 383). 
La preocupación a que alude el salmista consiste, pues, en el temor a ser condenado a las penas eternas ${ }^{21}$. El pedir a Dios que no le arguya cuando esté indignado o que no le enmiende cuanto esté airado, lo interpreta nuestro exégeta como la súplica del «salmista» 22 de que no se le aumenten los males que ya sufre, vistos como dardos lanzados por Dios, y que enumera a continuación en actitud confesante ${ }^{23}$.

\subsubsection{Las distintas unidades (vv. 4-27; $n^{\text {os } 5-27)}$}

En atención a las características de la enarratio, en lugar de tomar como punto de partida la sección y, dentro de ella, examinar las distintas unidades, procederemos en sentido inverso: tomamos como punto de partida las unidades $\mathrm{y}$, dentro de ellas, contemplamos lo referente a las secciones B y C.

\subsection{1. «Unidad segunda», sección B: Males del cuerpo (descripción y cau-} sas).

El santo toma pie de la primera parte del versículo cuarto del salmo: $M i$ carne no conoce la salud. No piensa aquí en las enfermedades concretas que pueda sufrir una persona en un momento determinado de su vida, sino en la enfermedad que va unida a la misma condición humana. De forma genérica la describe en estos términos:

21. «Nam utique arguet eos quibus dicet: Esuriui, et non dedistis mihi manducare; sitiui, et non potastis me et cetera quae ibi prosequens, quamdam inhumanitatem et sterilitatem increpitat malis ad sinistram constitutis, quibus dicitur: Ite in ignem aeternum, qui paratus est diabolo et angelis eius (Mt 25,41-42). Haec iste graviora formidans, excepta uita ista, in cuius malis plangit et gemit, rogat et dicit: Domine, ne in indignatione tua arguas me neque in ira tua emendes me» (en. Ps. 37 3: 383-384).

22. Cf. lo dicho antes sobre la exégesis prosopológica.

23. «Tamquam dicens Deo: Quoniam iam ista quae patior multa sunt, magna sunt, quaeso ut sufficiant. Et incipit illa enumerare satisfaciens Deo, offerens illa quae patitur, ne peiora patiatur: Quoniam sagittae tuae infixae sunt mihi et confirmasti super me manum tuam» (en. Ps. 37,4: 384). 
Llevamos, de hecho, un cuerpo mortal..., repleto de tentaciones, lleno de afanes, sujeto a dolores corporales, sometido a la indigencia, mutable, débil hasta cuando está sano, justamente porque su salud no es plena ${ }^{24}$.

Pero la fenomenología de esa falta de salud la descubre en tres dolencias concretas: el hambre, la sed y el cansancio o fatiga:

Sientes hambre; la sed lleva a la muerte si no se la satisface. En efecto, el alimento es la medicación contra (la enfermedad de)l hambre, la bebida es la medicación para la sed, y el sueño la medicación para el cansancio. Suspende dicha medicación y mira si no matan los males que existen. Si, retirados dichos medicamentos, no aparece la enfermedad, he ahí la salud. Si, por el contrario, aún tienes algo que te puede conducir a la muerte si no comes, no presumas de salud; espera, más bien, gimiendo la redención del cuerpo 25 .

Ante esta realidad, quienes debidamente hacen uso de su inteligencia y quienes se recuerdan del «sábado» comprenden que no es propiamente salud lo que en esta vida recibe tal nombre ${ }^{26}$. Más que salud es enfermedad. Pero no es salud sólo comparada con otra más plena, la que se poseerá en el descanso eterno, en el que el cuerpo corruptible se revestirá de incorrupción y el cuerpo mortal se revestirá de inmortalidad 27.

El versículo cuarto, además de indicar en qué consisten esos dardos clavados por Dios en la carne humana (Mi carne no conoce la salud), señala la causa de los mismos: la ira, la venganza divina ${ }^{28}$. Ira que tiene su origen en el

24. «Etenim portamus corpus mortale..., plenum tentationibus, plenum sollicitudinibus, obnoxium doloribus corporalibus, obnoxium indigentiis, mutabile, languidum et cum sanum est, quia utique nondum plene sanum» (en. Ps. 37,5:384-385).

25. «Esuries, sitis interficit, si subuentum non fuerit. Medicamentum enim famis est cibus, et medicamentum sitis est potus, et medicamentum fatigationis est somnus. Detrahe ista medicamenta, uide si non interficiunt illa quae existunt. Si sepositis istis non sunt morbi, est sanitas. Si autem habes aliquid quod te possit interficere, nisi manducaueris; noli gloriari de sanitate, sed gemens expecta redemptionem corporis tui» (en. Ps. 37,5:385).

26. «Nam unde dicebat: Non est sanitas in carne mea, nisi quia ista quae huius uitae dicitur sanitas, bene intellegentibus et sabbatum recordantibus non est utique sanitas?» (en. Ps. 37,5:385).

27. «... et ipsa recordatio sabbati, et nondum retentio, facit me nondum gaudere, et agnoscere nec sanitatem esse in ipsa carne, neque dici debere, cum comparo istam sanitatem illi sanitati quam habebo in requie sempiterna, ubi corruptibile hoc induet incorruptionem, et mortale hoc induet inmortalitatem; et uideo quia in illius sanitatis comparatione, ista sanitas morbus est» (en. Ps. 37,5: 386).

28. «Non est sanitas in carne mea a uultu irae tuae. Iam haec dicebat quae hic patiebatur; et tamen hoc iam de ira Domini, quia et de uindicta Domini... Unde ergo sagittae infi- 
pecado de Adán: a él se debe, en efecto, la mortalidad que sufre el hombre, causa, a su vez, de todos los males que le afligen ${ }^{29}$. Por eso habla de enfermedad «natural» 30 .

La segunda parte del mismo versículo cuarto abunda en el relato de las dolencias: Mis huesos desconocen la paz a causa de mis pecados. Pero, en vez de detenerse en ellas, el exégeta emprende otro camino: averiguar si tales palabras han de atribuirse a la Cabeza o al Cuerpo, dentro de la doctrina del totus Christus, cuya importancia como clave agustiniana de lectura de los salmos ya hemos señalado. El nuevo camino lo abandona pronto para volver al anterior, el de las dolencias que sufre en hombre, mas para introducir otro factor: el de la justicia de Dios o, visto desde la otra vertiente, el de la responsabilidad del hombre.

Si la primera parte del versículo cuarto señalaba que la causa de las dolencias estaba en la ira de Dios (a uultu irae tuae), la segunda atribuye al hombre la responsabilidad (a facie peccatorum meorum). Esta precisión del texto sálmico permite al santo afirmar la absoluta justicia del proceder de Dios, la legitimidad de su ira, pues detrás de ella está el pecado del hombre ${ }^{31}$. Esta responsabilidad la explicita aún más en el versículo quinto: Porque mis iniquidades irguieron mi cabeza, como una pesada carga gravaban sobre mí. Antepone la causa, la propia iniquidad que tiene por padre al orgullo; le sigue el efecto, la pesada carga de la enfermedad ${ }^{32}$.

xae? Ipsam poenam, ipsam uindictam, et forte dolores quos hic necesse est pati, et animi et corporis, ipsas dicit sagittas» (en. Ps. 37,5: 384-385).

29. «De qua uindicta? Quam excepit de Adam. Non enim in illum non est uindicatum, aut frustra dixerat Deus: Morte morieris (Gen 2,17); aut aliquid patimur in ista uita, nisi ex illa morte quam meruimus primo peccato» (en. Ps. 37,5:384).

30. «Iste naturalis quidam morbus est, quia natura nobis facta est poena ex uindicta. Primo homini quod erat poena, natura nobis est. Vnde dicit Apostolus: Fuimus et nos natura filii irae, sicut et ceteri (Ef. 2,5). Natura filii irae, hoc est, portantes uindictam» (en. Ps. 37,5: 385).

31. «Sed fortasse iniuste tibi Deus iratus est, o Adam, o genus humanum, iniuste iratus est Deus! Quia dixisti iam agnoscens ipsam poenam tuam, iam in corpore Christi constitutus homo: Non est sanitas in carne mea a uultu irae tuae. Expone iustitiam irae Dei; ne te excusare uidearis, illum accusare. Sequere, et dic unde ira Domini. Non est sanitas in carne mea a uultu irae tuae; non est pax ossibus meis. Repetiuit id quod dixit: Non est sanitas in carne mea; hoc est enim: non est pax ossibus meis. Non autem repetiuit: a uultu irae tuae, sed causam dixit irae Dei: non est pax, inquit, ossibus meis a facie peccatorum meorum» (en. Ps. 37,7: 387-388).

32. «Quoniam iniquitates meae sustulerunt caput meum, sicut fascis grauis gravatae sunt super me. Et hic causam praemisit, et efectum subiecit; quid unde contigerit dixit: Iniquitates meae sustulerunt caput meum. Nemo enim superbus nisi iniquus, cui sustollitur caput. Sursum tollitur, qui erigit caput aduersum Deum... Ille qui prior noluit audire praeceptum, 
La enfermedad por su propia naturaleza acarrea degeneración. El versículo sexto destapa precisamente la degeneración de los males causados por el orgullo: Mis heridas se llenaron de podredumbre y exhalan un olor fétido. Desde el ámbito físico, de común experiencia, es fácil al predicador pasar al moral, a la fetidez de los pecados, que percibirá toda alma que tenga sano el sentido del olfato del alma ${ }^{33}$. Es el punto más distante de la reflexión del predicador, guiado por el texto del salmo que comenta. Partió de la «natural» enfermedad humana; la causa de la misma le condujo a hablar del pecado del hombre cuyo origen fue el orgullo que, al no ser cortado a tiempo, llevó los miembros enfermos a la putrefacción y a la enfermedad ${ }^{34}$. Mas, para la fe cristiana, la putrefacción y la fetidez no tienen la última palabra. A pesar de que el cadáver de Lázaro ya olía mal por haberse producido la muerte cuatro días antes, Jesús le resucitó, hizo desaparecer la fetidez y le devolvió la salud ${ }^{35}$.

Antes de seguir adelante, es preciso retroceder un poco. El exégeta ha interpretado los dardos del versículo tercero (porque tus dardos se han clavado en mí y has puesto tu mano sobre mí) en el sentido expuesto: las dolencias que sufre todo hombre. Pero a esa interpretación añadió otra, consistente en ver los dardos como símbolo de las palabras de Dios:

No obstante, también solemos ver en los dardos las palabras de Dios. Pero, si fueron ellas las que nos golpearon, ¿podría él (el salmista) sentir tal dolor? Las palabras de Dios, en cuanto equiparadas a dardos, encienden el amor, no provocan dolor. $\mathrm{O}_{i}$ acaso habla así porque hasta el mismo amor no puede existir sin dolor? En efecto, es de necesidad que cause dolor aquello que amamos y no poseemos. Pues quien posee el objeto de su amor ama, pero sin sen-

sustulit iniquitas ipsius caput aduersus Deum. Et quia iniquitates sustulerunt caput eius, quid illi fecit Deus? Sicut fascis grauis grauatae sunt super me. Leuitatis est erigere caput, quasi nihil portat qui erigit caput. Quia ergo leue est quod potest erigi, accipit pondus unde possit comprimi. Conuertitur enim labor eius in caput eius, et iniquitas eius in uerticem eius descendit» (en. Ps. 37,8: 388).

33. «Computruerunt et putuerunt liuores mei. Iam qui liuores habet, non est sanus. Adde quia ipsi liuores computruerunt et putuerunt. Vnde putuerunt? Quia computruerunt. Iam quomodo hic explicetur in uita humana quis hoc non nouit? Habeat quis sanum olfactum animae, sentit quomodo puteant peccata» (en. Ps. 37,9:388).

34. San Agustín quiere decir, sin duda, que la condición enfermiza del hombre le mantiene y agrava el pecado, causa, a su vez, de dicha situación.

35. En el texto no hay ninguna referencia a dicha escena del evangelio de Juan (Jn 11,1-44), pero juzgamos probable que Agustín pensara en ella. A ese respecto puede ser de interés leer la interpretación moral que el santo hace de las tres resurrecciones que, según los evangelios, realizó Jesús (cf. s. 139 A: PLS 2,499-501; 98,3,3-7,7: PL 38,592-595; 128,12.14: PL 38,720). 
tir dolor; en cambio, como dije, quien ama y aún no posee el objeto de su amor, es inevitable que gima en su dolor. He aquí la razón de las palabras, puestas en boca de la Iglesia, esposa de Cristo, en el Cantar de los cantares: Porque estoy herida de amor (Cant 2,5;5,8). Dijo que estaba herida de amor. Amaba, en efecto, algo que aún no poseía y el no poseerlo aún le causaba dolor ${ }^{36}$.

Esta interpretación no es nueva en él ${ }^{37}$. Tampoco le aparta del tema de la enfermedad. Efectivamente el santo sigue hablando de herida y de dolor. La diferencia está en la naturaleza de la herida: es la del amor. Aquí no se trata de amor humano, sino divino, puesto que los dardos que lo encienden son palabras divinas. Pero no deja de ser significativo que el santo asocie los dos males, el puramente físico y el psicológico del amor ${ }^{38}$. Tanto uno como otro reclaman curación.

\subsection{2. «Unidad segunda», sección C: Males del cuerpo (referencia cristo- lógica).}

Un olor desagradable sugiere, por contraste, otro olor grato. El mal olor de los pecados orienta el pensamiento del predicador hacia el buen olor de Cristo de que habla san Pablo en su segunda carta a los Corintios:

A esta fetidez de los pecados era contrario aquel olor del que dice el Apóstol: Somos para Dios el buen olor de Cristo en todo lugar, en aquellos que se

36. «Solemus tamen et uerba Dei sagittas accipere; sed numquid ab his posset iste sic dolere se percuti? Verba Dei tamquam sagittae excitant amorem, non dolorem. An quia et ipse amor non potest esse sine dolore? Quidquid enim amamus et non habemus, necesse est ut doleamus. Nam ille et amat et non dolet, qui habet quod amat; qui autem amat, ut dixi, et nondum habet quod amat, necesse est ut in dolore gemat. Inde illud in persona ecclesiae sponsa Christi in Cantico canticorum: Quoniam uulnerata caritate ego sum (Cant 2,5; 5,8). Vulnerata se dicit caritate: amabat enim quiddam, et nondum tenebat; dolebat quia nondum habebat» (en. Ps. 37,5: 385-386).

37. cf. En. Ps. 119,5 CC 40,1781; también 7,14; 44,16 CC 38,45-46,504; 54,24; 76,20 CC $39,674,1064 ; 126,9 ; 127,2 ; 139,14$ CC 40,1863-1864, 1868-1869,2021-2022; conf. 9,2,3 CC 27,134 .

38. Aunque es un mal, el dolor tiene siempre una función positiva que Agustín se encarga de poner de relieve: delata la enferdad e impulsa a buscar la curación: «Ergo si dolebat, uulnerata erat; sed hoc uulnus ad ueram sanitatem rapiebat. Qui hoc uulnere non fuerit uulneratus, ad ueram sanitatem non potest peruenire. Numquid ergo uulneratus semper erit in uulnere?» (en. Ps. 37,5: 386). 
salvan (2 Cor 2,15). Pero, ¿de dónde dimana eso, sino de la esperanza? ¿De dónde, sino del recuerdo del sábado? Una cosa, en efecto, lloramos en esta vida, otra aceptamos que tendrá lugar en aquella otra. Lo que se llora hiede; lo que se prevé para el futuro exhala buen olor. Por tanto, si no existiese un olor de tales características que nos invitase, nunca nos acordaríamos del sábado ${ }^{39}$.

El texto reclama un poco de atención. El predicador contrapone a la fetidez de los pecados el buen olor de Cristo. El buen olor de Cristo en cuanto presente en el hombre, pero no en cualquiera, sino en aquel que se salva ${ }^{40}$. El mismo hombre que es portador del mal olor lo es también del bueno. Si el mal olor proviene del pecado, el bueno resulta de la ausencia de pecado. Como esta impecabilidad no se da en esta vida, hay que posponerla para la otra. De ahí que el santo fundamente el despedir el buen olor de Cristo en la esperanza, esto es, en la futura condición de salvado. Si el cristiano se acuerda del sábado, es anhelando desprenderse del mal olor y exhalar el bueno. El arte retórico del orador le facilita marcar bien el contraste entre lo que se posee ahora y lo que se intuye para el futuro. Lo presente suscita llanto y hiede; lo que se prevé para el futuro exhala agradable perfume. Tal perfume es una invitación a tener siempre presente en la memoria el «sábado», es decir, el sábado eterno.

Aunque esa realidad es futura en cuanto a su plenitud, los cristianos ya participan de ella por obra del Espíritu. Es esa posesión inicial la que hace que digan a Cristo, esposo de las almas: Corremos tras el olor de tus ungüentos (Cant. 1,3) y, a la vez, que tomen las medidas que lo posibilitan, esto es, apartar el olfato de los pecados y, volviéndose hacia tal olor, respirar un poquito. En efecto, si no nos llega el mal olor de nuestros pecados, nunca

39. «Cui putori peccatorum contrarius erat odor ille, de quo dicit Apostolus: Christi bonus odor sumus Deo in omni loco, iis qui salui fiunt (2 Cor 2,15). Sed unde, nisi de spe? Vnde, nisi de recordatione sabbati? Aliud enim plangimus in hac uita, aliud praesumimus in illa uita. Quod plagitur, putet; quod praesumitur, fragrat. Ergo nisi esset ille talis odor qui nos inuitaret, numquam sabbatum recordaremur» (en. Ps. 37,9:388).

40. Las palabras iis qui salui fiunt son traducidas con frecuencia: para los que se salvan. La traducción exacta, sin embargo, parece debe ser esta: en aquellos que se salvan. Así lo pide el contexto y, sobre todo, el hecho de que la forma habitual de la frase latina en san Agustín es in iis qui salui fiunt (cf. c. mend. 18,36 CSEL 41,520; Simpl. 1,1,17 CC 44,21; s. 273,5,5 PL 38,1250; 312,3,3 PL 38,1421; qu. 2,24 CSEL 28/2,104; en. Ps. 44,22 CC 38,510; 92,2 CC 39,1292; praed. sanct. 20,41 PL 44,990; bapt. 3,13,18 CSEL 51,208). 
haremos entre gemidos la oración del salmista: Mis heridas se llenaron de podredumbre y exhalaban un olor fétido a causa de mi necedad ${ }^{41}$.

En definitiva, según el predicador estamos ante un viaje de ida y vuelta: la experiencia del mal olor que desprenden los propios pecados suscita el sollozo y el llanto, que es expresión silenciosa del deseo del buen olor de Cristo; a su vez, la participación inicial en el buen olor de Cristo, gracias al Espíritu, hace percibir más intensamente esa fetidez del pecado y enciende el deseo de correr tras el buen olor de los ungüentos de Cristo, buen olor que nace de la ausencia de toda enfermedad, de la posesión de la salud plena. Quien tal aroma desprende es Cristo resucitado, el hombre totalmente restablecido y curado, porque ya no tendrá necesidad de nada. Desde la salud, el pecado le llevó a la podredumbre y a la fetidez; el conocimiento y el deseo de poseer en plenitud el buen olor de Cristo -lo contrario a la fetidez del pecado-, olor del que el Espíritu le ha hecho ya partícipe, le conducirá a apartarse del pecado y le llevará a la salud plena.

El versículo séptimo da pie al predicador para insistir en la condición enfermiza del hombre: Las miserias me llenan de aflicción y me hallo encorvado hasta abajo. El término «encorvado» 42 le permite traer a colación de nuevo el orgullo como causa última de esa curvatura originada por los pecados y, por contraste, la humildad que permite el enderezamiento ${ }^{43}$. La sección dedicada a los dolores corporales concluye con la invitación a vivir desde la esperanza: En medio de estas miserias, gima para recibir lo anhelado; tenga en su memoria el sábado para merecer llegar a él ${ }^{44}$. En línea con lo indicado anteriormente, podemos glosarlo así: Hallándose en medio de tan fétidos olores, gima para merecer poseer, por medio de una vida santa, el buen olor que desprende Cristo resucitado y glorioso.

41. «Sed quia habemus per Spiritum ipsum odorem, ut dicamus sponso nostro: Post odorem unguentorum tuorum curremus, auertimus a putoribus nostris olfactum et conuertentes nos ad ipsum aliquantum respiramus. Sed nisi ad nos oleant et mala nostra, numquam istis gemitibus confitemur: Computruerunt et putuerunt liuores mei. Vnde? A facie insipientiae meae. Unde dixit superius: $A$ facie peccatorum meorum; inde nunc: $A$ facie insipientiae meae» (en. Ps. 37,9:388-389).

42. Curvatura que es interpretada en términos paulinos: «Curuatur enim ille qui dicit: Corpus enim quod corrumpitur aggrauat animam, et deprimit terrena inhabitatio sensum multa cogitantem (Sab 9,15» (en. Ps. 37,10: 389).

43. «Miseriis afflictus sum et curuatus sum usque in finem. Vnde curuatus est? Quia elatus erat. Si fueris humilis, erigeris; si fueris elatus, curuaueris; non enim deerit Deo pondus unde te curuet. Illud erit pondus, fascis peccatorum tuorum, hoc replicabitur in caput tuum, et curuaueris. Quid est autem curuari? Non se posse erigere» (en. Ps. 37,10: 389).

44. «In his gemat ut illud accipiat, recordetur sabbatum, ut ad sabbatum peruenire mereatur» (en. Ps. 37,10: 389). 
4.7.3.3.2.1. «Unidad primera», sección B: Males del alma (descripción y causas).

$\mathrm{Al}$ término de la sección anterior, el predicador citaba el texto del libro de la Sabiduría, según el cual la morada terrena abruma al espíritu ocupado en pensar muchas cosas (Sap 9,15) 45. La dispersión del espíritu aquí aludida la va a desarrollar con más amplitud a continuación. Con esa dispersión vienen a identificarse los males del alma, de que se ocupa esta «unidad».

El primer versículo del salmo que corresponde a esta que llamamos «unidad primera» es el octavo, que tiene este tenor literal: Porque mi alma está llena de «ilusiones» 46. Es el segundo motivo por el que el salmista camina en tristeza continua ${ }^{47}$, siendo el primero la falsa de salud corporal. Tristeza que tendrá un término: cuando el alma se despoje de sus imágenes y fantasías y el cuerpo se revista de la verdadera salud que es la inmortalidad 48.

Si el predicador había encontrado grandes las dolencias del cuerpo, no considera menores las del alma. Estas son sus palabras:

¡Cuántas son las «ilusiones» del alma! Si quisiera contarlas, ¿cuándo hallaría el tiempo suficiente? ¿Qué persona no las sufre en su alma? El alma está llena de «ilusiones»: esta es mi breve advertencia. A causa de las mismas «ilusiones», apenas de vez en cuando se nos permite hacer auténtica oración ${ }^{49}$.

Hay que tomar nota de esta inmediata asociación entre las «ilusiones» y la oración. Lo que de hecho acontece en el espíritu humano lo refiere a continuación con cierto detenimiento:

De los cuerpos no sabemos pensar más que imágenes, y con frecuencia se agolpan las que no buscamos, y queremos ir de esta a aquella y pasar de aque-

45. Cf. nota 42 .

46. El versículo continúa en su segunda parte con: $Y$ mi alma no conoce salud alguna.Bajo el término «illusiones» entendemos tanto las imágenes que han entrado directamente por los sentidos como las que son creación de la imaginación (cf. De uera religione 34,64 CC 32,229).

47. Así acababa el versículo séptimo: tota die contristatus ambulabam.

48. Cf. nota 27.

49. «Quantae sint autem illusiones animae, si uoluero dicere, tempus quando sufficit? Cuius enim anima ista non patitur? Breue est quod admoneo, quomodo anima nostra completa est illusionibus. A facie ipsarum illusionum, aliquando uix orare permittitur» (en. Ps. 37,11: 389). 
lla a otra; y alguna vez quieres volver a aquello en lo que estabas pensando y dejar de lado lo que en ese momento está ocupando tu mente, y se te presenta otra cosa; quieres recordar lo que habías olvidado y no te viene a la mente y, en cambio, te viene otra cosa que no querías. ¿Dónde estaba lo que habías olvidado? ¿Por qué te vino luego a la mente cuando ya no lo buscabas y, en cambio, cuando lo buscabas, se te presentaron en su lugar innumerables cosas que no buscabas? ${ }^{50}$.

Con estas palabras el predicador no ha hecho sino ofrecer breves apuntes, a partir de los cuales los fieles pueden descubrir ellos mismos en qué consiste llorar las «ilusiones» del alma 51.

Pero ¿en qué consiste dicha «ilusión»? El predicador la juzga un castigo y la contrapone a la verdad 52 . La presencia de aquella implica la ausencia de esta. La «ilusión» es, pues, falta de verdad, pero no necesariamente mentira. La contraposición entre «ilusión» y verdad no se da en el ámbito moral, sino en el ontológico.

San Agustín distingue varios niveles de ser: el Ser Supremo (Dios), el ser espiritual (alma), el ser material (cuerpo), las imágenes de los cuerpos presentes en la memoria y que entraron allí por las puertas de los sentidos (phantasiae) y las creaciones de la propia imaginación a partir de los cuerpos o de sus imágenes (phantasmata) ${ }^{53}$. El término «ilusiones» se refiere en boca del predicador probablemente a estos dos últimos. Identificando la Verdad con el Ser Supremo, tanto las phantasiae como los phantasmata apenas poseen consistencia y, por tanto, verdad ontológica. Son simples ilusiones. El problema religioso a que hace referencia el santo es que tales «ilusiones» ocupan la mente en el momento de la oración y le impiden el contacto con la Verdad, con Dios.

50. «De corporibus cogitare non nouimus nisi imagines; et saepe inruunt quas non quaerimus, et uolumus ex hac in hanc ire, et ab illa in illam transire; et aliquando uis redire ad id quod cogitabas, et dimittere unde cogitas, et aliud tibi occurrit; uis recordare quod oblitus eras, et non tibi uenit in mentem, et uenit potius aliud quod nolebas. Vbi erat quod oblitus eras? Nam quare postea uenit in mentem cum iam non quaereretur? Cum autem quaereretur, occurrerunt pro illo innumerabilia quae non quaerebantur» (en. Ps. 37,11:389. 390).

51. «Rem dixi brevem, fratres; adspersi nescio quid uobis, quo accepto cetera uos ipsi cogitantes, inueniatis quid sit plangere illusiones animae nostrae» (en. Ps. 37,11:390).

52. «Accepit enim poenam illusionis, amisit ueritatem. Sicut enim poena est animae illusio, sic praemium animae ueritas» $(i b$.)

53. Cf. Confessiones 3,6,10 CC 27,32. «Et tantum ualet imaginis inlusio in anima mea, in carne mea, ut dormienti falsa uisa persuadeant quod uigilanti uera non possunt» ( $I b$. $10,30,41 \mathrm{CC} 27,176)$. 
Como ya hiciera a propósito de las dolencias del cuerpo, no se limita a señalarlas, sino que indica también su causa. Aquí, sin el apoyo del texto del salmo, se limita a indicar que se trata de un castigo, obviamente impuesto por Dios, pero sin hacer referencia ni a su ira ni a su venganza ${ }^{54}$. Castigo al que, sobra decirlo, el hombre se hizo merecedor por el pecado de Adán. En su orgullo, en la persona del primer hombre, se alejó de la Verdad y fue a parar a la sombra (Job 7,2), sombra de verdad.

\subsection{1. «Unidad primera», sección C: Males del alma (referencia cristológica).}

Si la «ilusión» es el castigo, la verdad es el premio 55 . Dios que castigó al hombre a sufrir la «ilusión» puso también a su disposición el medio para que pudiera acceder a la verdad: la encarnación de su Hijo, la Verdad misma:

Pero cuando nos hallábamos instalados en tales «ilusiones», vino la Verdad a nosotros. Nos halló cubiertos de «ilusiones», tomó nuestra carne o, mejor, tomó carne de nosotros, esto es, del género humano. Se hizo visible a los ojos de la carne, para sanar por medio de la fe a aquellos a los que había de mostrar la verdad, para que, una vez sanado el ojo, la Verdad se hiciera patente 56 .

A consecuencia del pecado, el hombre tiene dañado el ojo que le posibilita contemplar la Verdad. Tal es la razón por la que la Verdad en persona se hizo accesible al hombre, tomando su carne. Pero el hecho de la encarnación no comporta que el hombre tenga acceso directo e inmediato a la Verdad. Se le permite verla sólo al trasluz de su carne, esto es, mediante la fe, etapa previa -colirio que sana el ojo- al premio de la visión plena ${ }^{57}$. En efecto, durante su estancia en la tierra, Cristo veló lo que era, limitándose a dejar ver su carne. De haber mostrado a los ojos físicos su auténtico ser, lo hubiesen conocido los judíos y sus propios discípulos, quienes no le hubiesen pedido que les mostrase al Padre, puesto que quien le ve a él, ve también al Padre (Jn 14,8-

54. Cf. antes nota 28.

55. Cf. antes nota 52 .

56. «Sed in his illusionibus constituti cum essemus, uenit ad nos ueritas et inuenit nos coopertos illusionibus, suscepit carnem nostram, uel potius a nobis, id est a genere humano. Apparuit oculis carnis, ut per fidem sanaret eos quibus ueritatem fuerat monstraturus, ut sanato oculo ueritas patesceret» (en. Ps. 37,11:390).

57. «Ipse enim est ueritas, quam nobis promisit, cum caro eius uideretur, ut fides inchoaretur, cuius praemium ueritas esset» (en. Ps. 37,11: 390). 
9). Pero esta manifestación del Padre la reservaba como premio para quien cumpliese sus mandamientos y le amase (Jn 14,21) ${ }^{58}$. En consecuencia:

Si a los que aman les prometió como premio manifestarse a ellos, resulta claro que se nos promete aquella visión de tal Verdad que, una vez vista, ya no tengamos que decir: Mi alma está llena de «ilusiones» 59.

Qué significa esto para el hombre, a nivel físico y a nivel moral, lo revela el versículo siguiente del salmo, el noveno: estoy debilitado y humillado hasta el extremo. La conclusión la saca sólo quien contempla su estado de postración desde la excelsitud del «sábado» 60. En una cita del salmo 30: Yo dije en mi arrobamiento: he sido expulsado de la presencia de tus ojos (Sal 30,23) encuentra referida tal experiencia ${ }^{61}$, de la que fue paralela la visión de san Pablo 62. De ahí se deriva una doble actitud: de gemido y confesión del propio pecado, y de esperanza de que el Señor cumplirá su promesa de darse a conocer en su realidad divina, en su condición de Verdad ${ }^{63}$.

Tal es el rugido del corazón a que hace referencia la segunda parte del mismo versículo: El gemido de mi corazón era como un rugido. Para explicar tal rugido el predicador recurre a los siervos de Dios. El suyo no es un gemido de la carne, provocado por alguna desgracia que les haya sobrevenido, sino el gemido del corazón, no perceptible por el hombre: un gemido que surge

58. Cf. en. Ps. $37,11: 390$.

59. «Si ergo diligentibus eum hoc in praemio promisit, quia ostendet seipsum illis, manifestum est, quia illa uisio ueritatis talis nobis promittitur, qua uisa iam non dicamus: Impleta est anima mea illusionibus» (en. Ps. 37,11:390).

60. «Infirmatus sum et humiliatus sum usque nimis. Qui recordatur altitudinem sabbati, ipse uidet quantum sit humiliatus. Nam qui non potest cogitare quae sit illa quietis altitudo, non uidet ubi nunc sit» (en. Ps. 37,12: 390).

61. «Propterea alius psalmus dixit: Ego dixi in ecstasi mea: Proiectus sum a facie oculorum tuorum (Ps. 30,23). Assumpta enim mente uidit nescio quid sublime, et quod uidit nondum ibi totus erat; et quadam, si dici potest, quasi coruscatione facta luminis aeterni, ubi sensit non se ibi esse, quod potuit utcumque intellegere, uidit ubi esset, et quemadmodum malis humanis infirmatus et coarctatus esset, et ait: Ego dixi in ecstasi mea: Proiectus sum a facie oculorum tuorum. Tale est nescio quid quod uidi in ecstasi, ut inde sentiam quam longe sum, qui nondum ibi sum» (en. Ps. 37,12: 390-391).

62. «Iam ibi erat qui dixit assumptum se in tertium caelum, et ubi audiebat ineffabilia uerba, quae non licet homini loqui. Sed reuocatus est ad nos, ut gemeret prius perficiendus in infirmitate, et sic postea indueretur uirtute» (en. Ps. 37,12:391).

63. «Plangamus tamen et gemamus in confessione, agnoscamus ubi simus, recordemur sabbatum, et patienter expectemus quod ille promisit» (en. Ps. 37,12:391). 
ante el recuerdo del «sábado» 64. Pero lo que en verdad suscita ese rugido aparece señalado en la continuación del salmo: $Y$ ante mí está todo deseo (v. 10). Este deseo del salmista, que es también el del siervo de Dios, deseo que tiene puesto ante los ojos de Dios no ante los de los hombres, no es otra cosa que la oración:

Pues tu mismo deseo es tu oración, y si el deseo es continuo, continua es tu oración. En efecto, no dijo en vano el Apóstol: Orando sin cesar (1 Tes 5,17). ¿Acaso dice: Orad sin cesar, para que estemos continuamente de rodillas, postrados o con las manos levantadas? $\mathrm{O}$, si decimos que este es nuestro único modo de oración, pienso que nuestra oración no puede ser ininterrumpida 65 .

Tal interpretación del precepto paulino es evidentemente errónea, porque lo convierte en imposible de cumplir. Tiene que haber otra. Hela aquí:

Existe otra forma de orar sin cesar, interior, que se identifica con el deseo. Hagas lo que hagas, si deseas aquel «sábado», no cesas de orar. Si no quieres interrumpir tu oración, no ceses de desear. Tu deseo incesante es tu palabra incesante. Sólo callarás si dejas de amar. ¿Quiénes callaron? Aquellos de quienes se dijo: Al abundar la iniquidad, se enfriará la caridad de muchos (Mt 24,12). El enfriamiento de la caridad es el silencio del corazón; el ardor de la caridad es el grito del corazón. Si siempre permanece la caridad, estás gritan-

64. «Rugiebam a gemitu cordis mei. Adtenditis plerumque interpellare gemitibus seruos Dei, et quaeritur causa; et non apparet nisi gemitus alicuius serui Dei; si tamen ad aures hominis circa illum positi perueniret. Est enim gemitus occultus qui ab homine non auditur; tamen si tanta occupauerit cor cogitatio desiderii cuiusdam, ut uoce clariore exprimatur uulnus interioris hominis, quaeritur causa; et dicit homo apud semetipsum: Forte illud est unde gemit, et forte illud illi factum est. Quis potest intelligere, nisi ille in cuius oculis et auribus gemit? Propterea rugiebam, inquit, a gemitu cordis mei, quia homines si quando audiunt gemitum hominis plerumque gemitum carnis audiunt; gementem a gemitu cordis non audiunt. Abstulit nescio quis res huius; rugiebat, sed non a gemitu cordis: alius, quia extulit filium...; omnes isti a gemitu carnis rugiunt. At uero seruus Dei, quia ex recordatione sabbati rugit, ubi est regnum Dei, quod caro et sanguis non possidebunt (1 Cor 15,50$)$ » (en. Ps. 37,$13 ; 391$ ).

65. «Ipsum enim desiderium tuum oratio tua est; et si continuum desiderium, continua oratio. Non enim frustra dixit Apostolus: Sine intermissione orantes (1 Tes 5,17). Numquid sine intermissione genu flectimus, corpus prosternimus, aut manus levamus, ut dicat: Sine intermissione orate? Aut si sic dicimus nos orare, hoc puto sine intermissione non possumus facere» (en. Ps. 37,14: 392). 
do; si siempre estás gritando, siempre deseas; si deseas, es que te acuerdas del descanso 66 .

El predicador, siempre con los pies en la tierra, expone la necesidad de tomar conciencia de ante quién está ese rugido del corazón y de considerar, en consecuencia, cuál ha de ser la naturaleza del deseo, pues a veces el hombre pide lo que no debe, esto es, algo que no cuadra con la santidad de Dios ${ }^{67}$.

En el último versículo correspondiente a esta «unidad primera» el salmista refiere la turbación de su corazón, debida a que le abandonó su fortaleza, hecho debido a su vez a que sus ojos carecen de luz ${ }^{68}$. Aquí el exégeta remite de nuevo al Génesis. En el Paraíso Dios era la luz de sus ojos, pero al ofenderle el hombre huyó a la sombra de los árboles y, ya en medio de ellos, carecía de la luz que antes le procuraba gozo. Una experiencia que tienen, tras Adán, todos sus descendientes ${ }^{69}$. Lejos de Dios, Luz y Verdad, el hombre se encuentra en la sombra, equivalente a las «ilusiones» de que hablaba el versículo octavo en que empieza esta «unidad primera». Aunque no hace mención explícita de ellas, sin duda están en la mente del predicador.

Pero el pastor no se queda en la obra del primer Adán. De inmediato salta al segundo, a Cristo. Aunque el cristiano ya esté integrado en Él, la luz de sus ojos aún no está con él. Es ciertamente como los que aún se acuerdan del sábado, quienes lo ven en esperanza, pero aún no poseen la luz de la que se dice: Me mostraré a Él (Jn 14,21). Poseemos algo de luz porque somos hijos

66. «Est alia interior sine intermissione oratio, quae est desiderium. Quidquid aliud agas, si desideras illud sabbatum, non intermittis orare. Si non uis intermittere orare, noli intermittere desiderare. Continuum desiderium tuum, continua uox tua est. Tacebis, si amare destiteris. Qui tacuerunt? De quibus dictum est: Quoniam abundauit iniquitas, refrigescit caritas multorum (Mt 24,12). Frigus caritatis, silentium cordis est; flagrantia caritatis, clamor cordis est. Si semper manet caritas, semper clamas; si semper clamas, semper desideras; si desideras, requiem recordaris» (en. Ps. 37,14: 392).

67. «Et rugitus cordis tui ante quem sit, oportet ut intellegas. Iam quale disiderium debeat esse ante oculos Dei, considera... Nam aliquando oramus quod non debemus» (en. Ps. 37,14: 392).

68. «Cor meum conturbatum est. Vnde corturbatum est?... Vnde hoc? Quia deseruit me fortitudo mea... Vnde deseruit fortutudo? Et lumen oculorum meorum non est mecum» (en. Ps. 37,15: 392-393).

69. «Latuerat ergo Adam Iumen oculorum ipsius. Nam lumen oculorum ipsius ipse Deus erat; quem cum offendisset, fugit ad umbram, et abscondit se inter ligna paradisi (Gen 3,8). Pauebat a facie Dei, et quaesiuit umbram arborum. Iam inter arbores lumen oculorum non habebat, ad quod gaudere consueuerat. Si ergo ille de origine, et nos de propagine» (en. Ps. 37,15: 393). 
de Dios, cosa que aceptamos por fe, pero aún no es la luz por la que le veremos. Es la luz de la fe y la esperanza 70 .

En síntesis, estos son los términos esenciales que ha manejado el santo al hilo del salmo, obviamente dirigido por él hacia donde le interesaba. El alma está enferma de «ilusiones» (imágenes y fantasías), castigo de Dios, merecido a causa del pecado de origen. Si la «ilusión» significa la enfermedad, la salud representa la Verdad. Entre una y otra, como camino de la primera hacia la segunda, el predicador introduce la encarnación. Todo ello en un contexto de oración con mención explícita de los siervos de Dios o monjes.

4.7.3.3.3.1. «Unidad tercera», sección B: Males ajenos (descripción y causas).

La persona humana tiene una triple relación: con el propio cuerpo, con el propio espíritu, con los demás hombres. Si el cuerpo y el espíritu son fuente de males, como hemos visto, también lo son los demás hombres. El resto de los versículos del salmo refieren, según el predicador, los «males ajenos», esto es, los causados por otros hombres 71 .

La descripción de los «males ajenos» ocupa 11 versículos del salmo, casi la mitad del mismo. En todos ellos habla Cristo, en unos en nombre propio, en otros en nombre de su cuerpo. Cuando habla en nombre propio, relata sufrimientos de su pasión. Es el caso de los versículos 12 (Mis amigos y mis allegados se me acercaron y se plantaron contra mí), 13 (Y hacían violencia los que buscaban mi alma; los que buscaban mis males hablaron vaciedad y todo el día tramaban el engaño), 14 (Pero yo como un sordo no oía y como un mudo no abría mi boca), 15 (Me he convertido en hombre que no oye y no tiene répli-

70. «... et redeunt ad illum secundum uel nouissimum Adam membra ista, quia nouissimus Adam in spiritum uiuificantem; et clamant de corpore eius in ista confessione: $E t$ lumen oculorum meorum non est mecum; iam confitens, iam redemptus, iam in corpore Christi est, et lumen oculorum ipsius non est cum ipso? Plane non est cum ipso; sed est quietem tamquam cernentium in spe; sed nondum est illud lumen de quo dicitur: Ostendam me ipsum illi (Jn 14,21). Est quiddam luminis, quia filii Dei sumus, et utique hoc in fide retinemus; sed nondum est illud lumen quod uidebimus... Nam modo lumen fidei et lumen spei est. Quandiu enim sumus in corpore, peregrinamur a Domino; per fidem enim ambulamus, non per speciem (2 Cor 5,6-7). Et quamdiu quod non uidemus speramus, per patientiam expectamus (Rom 8,25). Voces sunt ergo istae peregrinantium, nondum in patria constitutorum. Et recte dicit, et uere dicit, et si non sit dolosus, ueraciter confitetur: Et lumen oculorum meorum non est mecum» (en. Ps. 37,15: 393).

71. La exégesis moderna habla de los efectos sociales del pecado y consiguiente reacción del paciente (cf. L. Alonso SchöKel-C. CARNITI, Salmos, p. 568.570). 
ca en sus labios), 16 (Porque he esperado en ti, Señor; tú me escucharás, Señor Dios mío) y 21 (Los que devuelven males a cambio de bienes hablaban mal de mí, porque busqué la justicia) ${ }^{72}$.

En los otros versículos Cristo habla en nombre de su cuerpo. Los males a que hace referencia son tres: la maledicencia, el odio y el daño en los bienes materiales.

El primer mal lo causa la lengua de los enemigos ${ }^{73}$. Lo refiere el v. 17: Porque he dicho: Que jamás exulten mis enemigos a costa mía; y cuando tropezaron mis pies, dijeron enormidades contra mí. El énfasis del predicador recae precisamente sobre ese mal producido por la lengua:

A veces, pues, tal como es esta vida, tropiezan nuestros pies y caen en algún pecado. En ese momento surgen las lenguas sumamente inicuas de los enemigos. De ahí podemos entender qué es lo que buscaban cuando callaban. Hablan entonces con aspereza y sin mansedumbre, gozosos por haber hallado lo que debían llorar ${ }^{74}$.

El segundo mal es el del odio. Lo expresa el v. 20, que en la versión de Agustín, sonaba así: En cambio mis enemigos viven y se han impuesto sobre mí y se han multiplicado quienes me odiaban inicuamente. El comentario del santo se fija precisamente en ese odio:

Odian a quien quiere para ellos el bien. Ellos que no serían buenos ni aunque devolviesen males por males y, si no devolviesen bienes por bienes, serían ingratos. Pero los que odian inicuamente devuelven males a cambio de bienes. Así fueron los judíos ${ }^{75}$.

72. «Amici mei et proximi mei aduersum me adpropinquauerunt et steterunt (v. 12). Et uim faciebant qui quaerebant animam meam; qui quaerebant animam meam locuti sunt uanitatem, et dolum tota die meditabantur (v.13). Ego autem uelut surdus non audiebam, et sicut mutus non aperiens os suum (v. 14). Et factus sum sicut homo non audiens et non habens in ore suo redargutiones (v. 15). Quoniam in te, Domine, speraui, tu exaudies, Domine, Deus meus (v. 16). Detrahebant mihi qui retribuunt mala pro bonis, quoniam persecutus sum iustitiam (v. 21).

73. Entre los efectos sociales, es el abuso verbal lo que más siente el orante (L. ALONSo SCHÖKEL-C. CARNITI, Salmos, p. 568).

74. «Aliquando enim, ut est ista uita, commouentur pedes nostri, et labuntur in aliquo peccato; ibi exurgunt linguae nequissimae inimicorum. Loquuntur tunc aspere immites, gaudentes se invenisse quod dolere debuerunt» (en. Ps. 37,22: 397).

75. «Bona sibi uolentem oderunt. Qui si redderent mala pro malis, boni non essent; qui si non redderent bona pro bonis, ingrati essent; reddunt autem mala pro bonis qui oderunt inique. Tales fuerunt Iudaei...» (en. Ps. 37,25: 399). 
El predicador recomienda vivamente no caer en él, cosa bien posible cuando se recibe una corrección:

Guardaos, pues, de este mal, hermanos: Se cuela de inmediato. Que ninguno de vosotros se considere exento de él, por haber dicho yo: tales eran los judíos. Si te corrige algún hermano tuyo, deseándote el bien, y le odias, te haces como ellos. Y ved, hermanos, cuán rápida y fácilmente acontece eso. Y evitad tan gran mal, pecado tan presto ${ }^{76}$.

El tercer mal es, indicábamos, el daño en los bienes. Este mal no está explicitado en ningún versículo del salmo. Es sólo un ejemplo, significativo, que pone el santo. El salmista, en el versículo 18, manifiesta su disponibilidad a ser azotado, actitud que el predicador alaba 77 . El versículo 19 alude al dolor que le producen los azotes y la causa de los mismos: Mi dolor está siempre ante mí. Porque yo confieso mi maldad y siento preocupación por mi pecado. Uno de esos azotes es precisamente el daño en los bienes:

Escuchad, hermanos míos: Si alguien, quien sea, sufre daño (en sus bienes), se encuentra más propenso a decir: Lo he sufrido inmerecidamente, que a considerar por qué lo ha sufrido. Se duele del daño sufrido en su cartera, no del daño sufrido por la justicia. Si has pecado, siente dolor por tu tesoro interior; vacía está tu casa, pero tal vez está aún más vacío tu corazón ${ }^{78}$.

Utilizando una imagen médica, el santo lamenta que los hombres sientan el dolor que les produce la medicación y no el que les produce la herida ${ }^{79}$. En

76. «Cauete hoc malum, fratres, cito subintrat. Quia diximus: Tales erant Iudaei, ne putet unusquisque uestrum longe se esse exceptum. Corripiat te aliquis frater tuus, bonum tibi uolens; oderis illum et talis es. Et uidete quam cito fiat, quam facile; et uitatote tam magnum malum, tam agile peccatum» (en. Ps. 37,25: 399).

77. Poniéndola en relación con Prov. 3,11-12.

78. «Audite, fratres mei: Nescio quis si damnum patitur, proclivior est ut dicat: Indigne passus sum, quam ut consideret quare passus sit; dolens malum pecuniae, non dolens iustitiae. Si peccasti, thesaurum tuum interiorem dole; nihil habes in domo, sed forte inanior es corde» (en. Ps. 37,24: 398). «... tunc peius mortuus luxuriose uiuens, quam moriendo luxuriam finiens. Tunc ergo quando ista faciebat in domo tua, non solum mortuus erat, sed et putebat» (en. Ps. 37,24: 398).

79. «Et uere, fratres mei, uere dicam vobis, flagella sua dolent homines; quare flagellantur non dolent. Non erat sic iste... Ecce unde dolor. Non de flagello dolor; de uulnere, non de medicina. Nam flagellum medicamentum est contra peccata» (en. Ps. 37,24: 398). 
todo caso, no basta la confesión del propio pecado, si no va acompañada de la preocupación por él ${ }^{80}$. Su consejo es:

Da limosnas, redime tus pecados, disfrute el indigente de tu dádiva, para que también tú disfrutes de la dádiva de Dios 81 .

\subsection{2. «Unidad tercera», sección C: Males ajenos (referencia cristológica)}

En este apartado podemos hablar de referencia cristológica, pero no en el mismo sentido que en los anteriores. En ellos, la referencia era específica, es decir, ofrecía el remedio al mal concreto examinado. Aquí, en cambio, sólo hallamos referencias genéricas. A propósito del versículo 16: Porque yo he esperado en ti, Señor; tú me escucharás, Señor, Dios mío, comenta: «Te indicó lo que has de hacer, si tal vez te llega alguna tribulación» 82 . Y no deja de tener su interés el ejemplo concreto que pone: quien ha sido víctima de un falso testimonio 83 .

\subsubsection{Epílogo}

En el último versículo del salmo, Dios es presentado como «el Dios de mi salud» (Acude en mi socorro, Dios de mi salud). Esta salud es el denario que Dios dará a todos por igual, profetas, apóstoles, mártires y demás cristianos, al final de los tiempos. Es la salud sempiterna en que, contemplando la gloria de Dios y viendo su rostro, lo alabaremos eternamente, sin defecto, sin castigo alguno debido a la maldad cometida, sin la perversidad que es el pecado, ala-

80. «Ne securus sis, cum confessus fueris peccatum tuum, tamquam semper praeparatus ad confitendum et commitendum peccatum. Sic pronuntia iniquitatem tuam, ut curam geras pro peccato tuo. Quid est, curam gerere pro peccato tuo? Curam gerere pro uulnere tuo. Si diceres, curam geram pro uulnere meo, quid intelligeretur nisi: Dabo operam ut sanetur? Hoc est enim curam gerere pro delicto, semper niti, semper intendere, semper studiose et sedulo agere ut sanes peccatum» (en. Ps. 37,24:398).

81. «Fiant eleemosynae, redimantur peccata, gaudeat indigens de dato tuo, ut et tu gaudeas de dato Dei» (en. Ps. 37,24: 398).

82. «Monuit te quid facias, si forte occurrerit tribulatio» (en. Ps. 37,21: 396).

83. «Quaeris enim te defendere, et forte nemo accipit defensionem tuam. Iam tu perturbaris, quasi perdideris causam tuam, quia nullius habes defensionem aut testimonium. Custodi intus innocentiam tuam, ubi nemo opprimit causam tuam. Praeualuit in te falsum testimonium, sed apud homines; numquid apud Deum ualebit, ubi causa tua dicenda est?» (en. Ps. 37,21:396). 
bando a Dios, ya no suspirando por Él, sino unidos a Él, por quien hemos suspirado hasta el final y en quien nos alegramos ahora en la esperanza. Es el «sábado» en que Dios será nuestro bien, esto es, nuestra luz, nuestro pan, nuestra vida. En él encontramos nuestro bien, hallándonos lejos del cual nos fatigamos en nuestra peregrinación ${ }^{84}$. Adviértase en esta presentación la especificación ternaria del bien del hombre: Dios como luz, como pan y como vida. Es el «sábado», el descanso eterno, cuyo recuerdo sin la posesión nos produce ahora necesariamente dolor 85 .

\subsubsection{Comparación entre la Regla y en. Ps. 37}

El marco del análisis hecho de la en. Ps. 37 es la investigación sobre la estructura de la Regla de san Agustín. Creemos que el lector ha percibido ya en buena medida las convergencias estructurales. Hemos querido ponerla de relieve otorgando a los diferentes apartados la misma designación-creemos que sin violencia a la realidad del texto- con que venimos presentado los de la Regla. Hemos hablado del prólogo (n ${ }^{\circ} 1$ ); de la sección A (vv.1-3; nos 2-4); de las secciones B y C (vv. 4-22; nos 4-27), cada una de ellas con las respectivas «unidades» primera (vv. 8-11; nos 11-15), segunda (vv. 4-7; nos 4-10) y tercera (vv. 12-22; nos 16-27) 86; y, por último, del epílogo ( $\left.\mathrm{n}^{\circ} 28\right)$.

Pero los epígrafes, cuando son puramente convencionales, no bastan para mostrar la convergencia entre dos textos. De ahí la necesidad de mostrar que responden al contenido del texto mismo. Aunque lo hemos hecho en los análisis anteriores, conviene presentar ahora el resultado de forma más sistemática.

Prólogo. Al tratarse de dos textos que responden a géneros literarios diferentes, es lógico que el prólogo en que se hace la presentación del «docu-

84. «... in ipso fine accepturi sumus salutem sempiternam; ut contemplantes gloriam dei, et eius faciem intuentes, eum laudemus in aeternum, sine defectu, sine aliqua peruersitate peccati, laudantes Deum, et non iam suspirantes, sed inhaerentes illi, cui usque in finem suspirauimus, et in spe laetati sumus. In illa enim ciuitate erimus, ubi bonum nostrum deus est, lumen deus est, panis Deus est, uita Deus est; quidquid est bonum nostrum, a quo peregrinantes laboramus, in illo inueniemus» (en. Ps. 37,28: 401).

85. «In illo erit quies, quam modo recordantes necesse est ut doleamus. Illud enim sabbatum recordamur, in cuius recordatione tanta dicta sunt, et nos tanta dicere debemus, et dicentes numquam tacere, non ore, sed corde, quia sic ore tacemus, ut corde clamare possimus» (en. Ps. 37,28: 401).

86. En el análisis hemos partido de las unidades y dentro de ellas hemos integrado las secciones B y C. 
mento» varíe. Mientras el de la Regla, texto legislativo, alude a los preceptos que a continuación se darán, el de en. Ps. 37, texto de predicación y exegético, establece la relación entre las dos lecturas escuchadas por la asamblea litúrgica.

Sección $A$. En ambos textos señala la meta a que se pretende llegar. Expresada con diferentes términos, es idéntica en uno y otro texto. La Regla la expresa con in Deum; en. Ps. 37 con la idea del «sábado» o descanso eterno. Junto a esta convergencia fundamental, hay que señalar como divergencia el que no aparezca netamente expresado el caminar en común hacia la meta (unidad de almas y corazones de la Regla) ${ }^{87}$.

Sección B. Uno y otro texto presentan la debilidad o enfermedad de la condición humana; debilidad y enfermedad que en ambos textos encuentra una triple expresión, las tres «unidades» en nuestra terminología.

«Unidad primera». Se corresponde con el capítulo segundo de la Regla. Los dos textos se ocupan de la enfermedad del alma, aunque la Regla no utilice esa expresión. Tal enfermedad es mencionada explícitamente por en. Ps. 37: se trata de las «ilusiones» o imágenes que, procedentes del exterior, invaden el alma y dificultan o imposibilitan la oración, específicamente la de los siervos de Dios. Es, sin duda, la misma enfermedad que se sobreentiende en el segundo capítulo de la Regla, al menos cuando ordena que vayan de acuerdo corazón y palabras (R II,3) y, posiblemente, en el anterior que ordena que nadie se convierta en impedimento para el hermano que quiera hacer oración en el oratorio, si dispone de tiempo para ello ( $\mathrm{R} \mathrm{II,2).}$

«Unidad segunda». Se corresponde con los capítulos tercero y cuarto de la Regla. Tanto esta como en. Ps. 37 consideran en ella la enfermedad del cuerpo, enfermedad «natural». Uno y otro texto hacen referencia al hambre, la sed y la fatiga ${ }^{88}$. Aunque en. Ps. 37 habla sólo del amor divino, mientras la Regla, en su capítulo cuarto, tiene en su punto de mira el amor carnal, es significativo que también ese amor divino es presentado como herida que produce dolor, que la mantiene en la fenomenología de la enfermedad.

87. Decimos «expresado» porque la realidad está ciertamente sobreentendida. Basta pensar en la clave hermenéutica del santo: la doctrina del totus Christus. Desde ella, se hace imposible no caminar en unidad con los demás cristianos. Regla e en. Ps. 37 divergen también en que éste último texto contempla la posibilidad del fracaso, esto es, de la condenación, ausente del primero.

88. La regla no menciona la fatiga, pero la presupone al hablar de los conflictos que pueden surgir a propósito de los colchones y cobertores (R III,4), que obviamente se relacionan con el remedio a esa fatiga, es decir, con el descanso. Cf. Estructura (II), en Estudio Agustiniano 33 (1988) p. 32. 
«Unidad tercera». Se corresponde con los capítulos quinto, sexto y séptimo de la Regla. También aquí se mantiene el paralelismo en su aspecto más general, en cuanto que uno y otro documento se refieren a los males vinculados al aspecto social del hombre, los «males ajenos», según la terminología de en. Ps. 37. En los aspectos concretos, en ambos textos se mencionan el mal de la ofensa verbal y del odio (cf. R VI), y los relacionados con los bienes materiales, que lleva al predicador a recomendar compartirlos con los necesitados (R V). Pero su aparición en el curso de en. Ps. 37 aparece más bien como puramente circunstancial, por lo que no procede apoyar demasiado en ello la argumentación. En todo caso, siempre queda en pie la convergencia señalada, aunque no sea demasiado significativa. Además -nueva divergencia- el capítulo séptimo de la Regla no encuentra paralelo alguno en la «unidad tercera» de en. Ps. 37.

Sección C. Como ya señalamos, la ubicación de esta sección en en. Ps. 37 no es la misma que en la Regla. En. Ps. 37 no coloca la secuencia Sección B y Sección $\mathrm{C}$ de una forma global, sino en el interior de cada «unidad». Tras presentar cada enfermedad (corporal, espiritual o social), ofrece la respectiva referencia cristológica. Veámosla.

La «unidad primera» de la Regla presenta en su sección $\mathrm{C}$ la referencia cristológica, con valor de alternativa, a lo expuesto en la sección B. A los «espectáculos», exteriores o interiores, que pueden interrumpir o enturbiar la relación del siervo con Dios en su oración, opone otro espectáculo más bello, pero de belleza espiritual, que es Cristo, el Hijo de Dios encarnado ${ }^{89}$. Asimismo, a las «ilusiones» que padece el alma, esto es, a las imágenes que le llegan de los cuerpos e impiden la oración del cristiano, en. Ps. 37, en su «unidad primera», opone también a Cristo, la Verdad encarnada, aceptada por fe, y camino para llegar a la Verdad pura. Las diferencias entre la Regla y en. Ps. 37 son accidentales: de una parte, en. Ps. 37 menciona abiertamente las dolencias del alma, mientras que la Regla sólo las presupone, sin señalarlas explícitamente; de otra, mientras la Regla sigue el camino de la Belleza, en. Ps. 37 opta por el de la Verdad. Diferencia mínima, puesto que los trascendentales se identifican ${ }^{90}$.

En cuanto a la «unidad segunda», a las dolencias físicas del hambre, sed, fatiga y pasión sexual la Regla opone en su sección C el ardor por el buen olor de Cristo en una relación enigmática para el lector de la misma, pero que

89. Cf. Estructura (III), en Estudio Agustiniano 33 (1998) p. 248-254. 
puede aclararse desde en. Ps. 37. En efecto, en su «unidad segunda», a las dolencias físicas del hambre, sed y fatiga, fruto del pecado y causa de pecados, que pueden acabar en podredumbre y fetidez, el santo opone en el comentario del salmo el buen olor de Cristo (resucitado), consecuencia de haber recuperado la salud plena, reservada también para el hombre. Cristo es asimismo quien suscita el amor que hiere (Cant 2,5) y cuyo perfume arrastra tras de sí (Cant 1,3). Si antes (unidad primera de la Regla y de en. Ps. 37) nos movíamos en el ámbito de la fe, ahora nos movemos en el de la esperanza. Lo importante es que, en ambos textos y en ambos casos, la dolencia del hombre tiene una referencia cristológica con valor de alternativa. Esto es, la curación definitiva del mal que el hombre sufre se halla en Cristo y no en los remedios a los que el hombre suele recurrir. Respecto a la enfermedad psicológica del amor, es también Cristo, poseído ya definitivamente, quien la remediará.

En cuanto a la «unidad tercera» es más difícil establecer el paralelismo. La referencia cristológica, ya indicamos, es muy genérica: se limita a señalar que ciertas palabras del salmo tienen a Cristo como autor, pero con la única finalidad de mostrar al cristiano cómo ha de comportarse cuando llegue la tribulación, si es el caso. Al hablar de los «males ajenos» de la maledicencia, odio y daño en los bienes de bienes, cabía esperar la actitud de Cristo ante ellos, que se convertiría en referencia para los cristianos. Pero no es el caso.

Epílogo. Aquí tampoco hay paralelismo. En la Regla contiene normas prácticas sobre como comportarse frente al documento mismo; en en. Ps. 37 explicita el contenido de la sección A.

\subsubsection{Conclusiones generales}

Dejando aparte prólogo y epílogo, el resultado de la comparación: lo recoge el esquema de la p.76.

Con el cuadro delante es fácil extraer, al menos, un par de conclusiones. La primera de ellas, un paralelismo suficientemente amplio en estructura y en contenidos. Estructura y contenido que coinciden globalmente con los que hemos visto con anterioridad en otros textos como De uera religione ${ }^{91}$, el

90. Al respecto puede verse el ascenso a Dios en libro décimo de las Confessiones. Comienza por la belleza $(10,6,9$ : CC 27,159) y concluye con la Verdad $(10,26,37:$ CC 27,175$)$, para volver acto seguido a la Belleza, siempre antigua y siempre nueva $(10,27,38$ : CC 27,175).

91. Cf. Estructura (II), en Estudio Agustiniano 33 (1998) 5-53. 


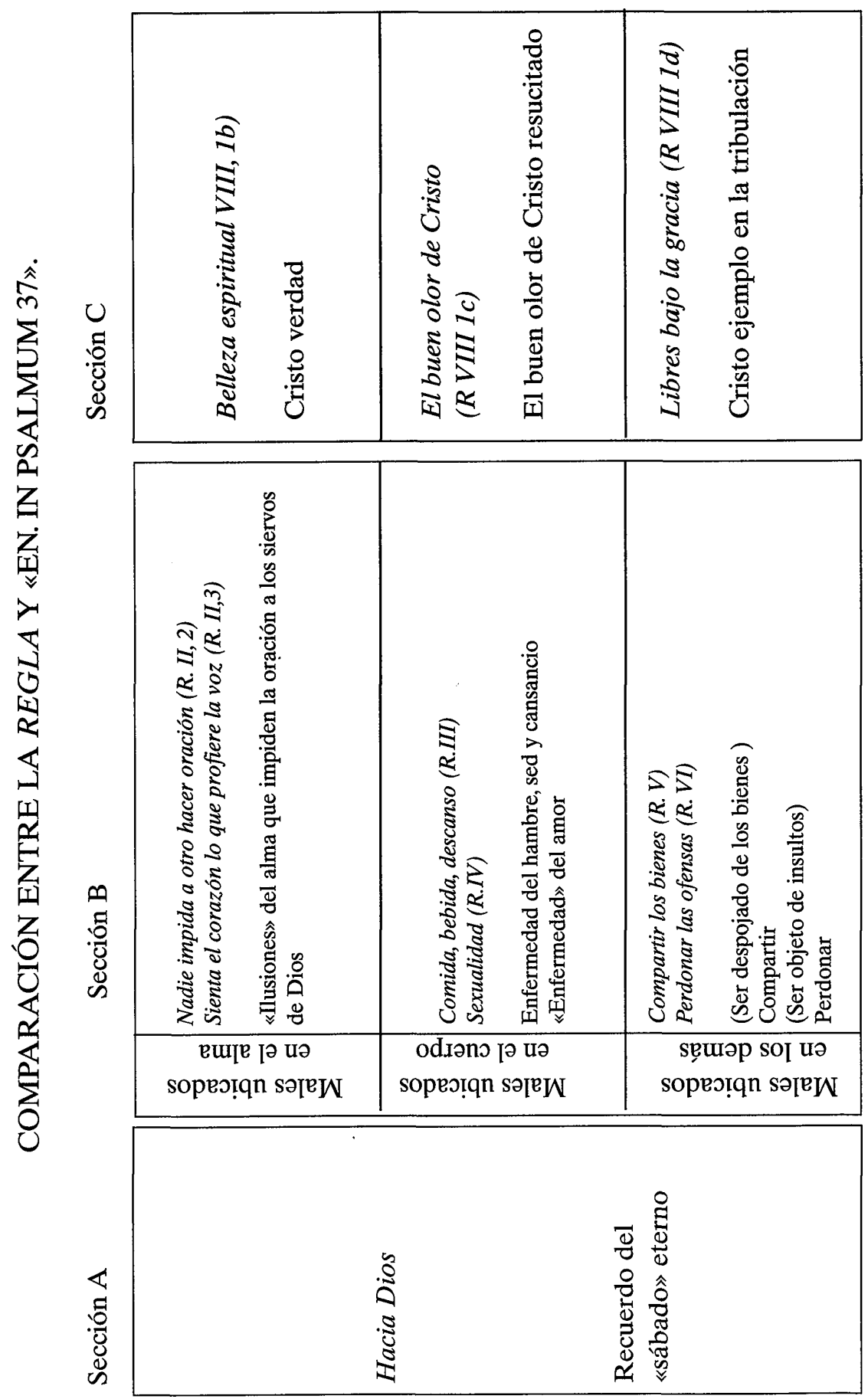


libro décimo de las Confessiones ${ }^{92}$, los nueve primeros libros de la misma obra ${ }^{93}$, la epistula $48{ }^{94}$, los sermones de Cuaresma 95 y De moribus ecclesiae 31, 65-67 96. Dejando de lado la Regla, el término de comparación de todos ellos, son ya siete ${ }^{97}$ los documentos escritos que mantienen con ligeras variantes el mismo esquema fundamental.

La segunda, que, a diferencia de los anteriores textos, la estructuración señalada en en. Ps. 37 no se apoya explícitamente ni en las tres prácticas ascéticas que son la oración, la limosna y el ayuno (cf. Mt 6), como en Epist. 48 y Sermones de Cuaresma, ni en las tres cupiditates o las tres concupiscencias de 1 Jn 2,16, como en De uera religione y Confessiones, ni en las virtudes cardinales, como quizá en De moribus ecclesiae. Su base es siempre antropológica en cuanto que considera, una tras otra, tres dimensiones del hombre: corporal, espiritual y social, detrás de las cuales están las tres partes de la filosofía: natural, racional y moral.

Respecto de la Regla cabe señalar, además de la diferencia de géneros literarios a que ya aludimos, los distintos destinatarios. La Regla se dirige a siervos de Dios, en. Ps. 37 a todo el pueblo cristiano. La coincidencia de contenidos, no obstante los diferentes destinatarios, ofrece también un punto a tener en cuenta a la hora de intentar comprender la naturaleza del monacato agustiniano.

(Continuará)

Pío DE LUIS

Estudio Teológico Agustiniano

Valladolid

92. Cf. Estructura (III), en Estudio Agustiniano 33 (1998) 227-270.

93. Cf. Estructura (IV) en Estudio Agustiniano 33 (1998) 487-524.

94. Cf. Estructura (V), en Estudio Agustiniano 34 (1999) 5-29.

95. Cf. Estructura (VI), en Estudio Agustiniano 33 (1999) 219-247.

96. Cf. Estructura (VI), en Estudio Agustiniano 33 (1999) 539-576.

97. C10 y C1-9 los consideramos como dos documentos porque fueron escritos en dos momentos diferentes, aunque no sea posible cuantificar el intervalo de tiempo. Lo cierto es que con el libro noveno acaba una primera redacción de la obra a la que luego se añadió el décimo, atendiendo a la petición de algunos hermanos (cf. Conf. 10,3,3-5,7 CC 27,156-158). 